\title{
DETECTION OF IMMUNOGENIC PROTEINS FROM Rickettsia conorii AND Rickettsia africae BY PROXIMITY LIGATION ASSAY BASED WESTERN BLOTTING (PLA WB)
}

\author{
AYMAR N'DJATCHI ${ }^{\mathrm{a} 1}$, ISSA BAGRE ${ }^{\mathrm{b}}$, MATHIEU ADOUKOFFI KRA ${ }^{\mathrm{c}}$ AND ADAMA COULIBALY

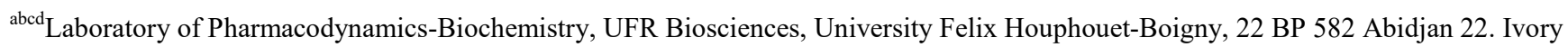 \\ Coast
}

\begin{abstract}
Rickettsia conorii, the causative agent of Mediterranean spotted fever (MSF) and Rickettsia africae, the etiologic agent of African tick-bite fever (ATBF), are strict intracellular bacteria transmitted by ticks belonging to the spotted fever group (SFG) Rickettsia. The laboratory diagnosis is based on serology, but remains not enough specific to provide the diagnosis at the species level. Here, we attempted to detecty immunogenic proteins specific from Rickettsia conorii and Rickettsia africae by proximity ligation assay based Western blotting (PLA WB). In general, we obtained better sensitivity and specificity of bands detection in PLA WB in case of proteins probed with IFA $R$. conorii or $R$. africae positive sera. In parallel, we have screened 20 rickettsial recombinant proteins by ELISA with sera infected by $R$. conorii and $R$. africae, respectively. We identified several potential markers which allowed infection due to $R$. conorii to be discriminated from those due to $R$. africae. Never the less, this technique must be optimized for use in laboratory diagnostic routine.
\end{abstract}

KEYWORDS: Rickettsia africae, Rickettsia conorii, Traditional Western Blot, Proximity Ligation Assay, Recombinant Proteins, Serodiagnosis, Test Operating Parameters

The spotted fever group (SFG) Rickettsia is Gramnegative obligated intracellular bacteria, contains about 25 different species including Rickettsia africae and Rickettsia conorii (Eremeeva and Dasch 2015). Rickettsia africae is responsible for the African tick bite fever (ATBF), transmitted by ticks of the Amblyomma genus, endemic in sub-Saharan Africa and the French West Indies (Parola and Paddock, 2012) (Parola et al., 1998). R. conorii, the agent of Mediterranean spotted fever transmitted by the brown dog tick Rhipicephalus sanguineus, is endemic in the Mediterranean area and in a few sub-Saharan countries (Parola et al., 2009) (Merhej et al., 2009). Actually, the clinical manifestations of these diseases show common symptoms such as flu-like manifestations (fever, chills, myalgia, and headache) (Parola and Paddock, 2012). The laboratory diagnosis of rickettsioses is based onserological testing (La and Raoult, 1997), cell cultureand molecular techniques (La and Raoult, 1997). Diagnosis by real-time PCR and PCR suicide is rapid and sensitive (La and Raoult, 1997). The genes most commonly used for detection are the $16 S$ rRNA, the citrate synthase (gltA), rOmpA and rOmp, respectively (Roux et al., 1997) (Renvoise et al., 2012). Recently, real-time PCR gain sensitivity and specificity by using new generation primers (Renvoise et al., 2012). Molecular detection was simplified by using directly the eschar swabs samples (Mouffok et al., 2011). ELISA (Fuller Laboratories) methods are also currently available for non-referenced laboratories which are focused on more specific reactivities to the lipopolysaccharide (LPS) antigens (IgG screening) and rOmpB protein antigens (IgG/IgM). To date, serological testing only allows identification of Rickettsiae at the group or clade level. Western blot and antigen adsorption have been also used in routine procedures allowing confirmation of serologic diagnosis obtained by conventional methods (Renvoise and Raoult, 2009). However, the major limitation that the crossadsorption presents is the large amount of antigen needed and that the technique is not always successful ( $\mathrm{La}$ and Raoult, 1997). Diagnosing rickettsioses is still a great challenge. Research has been focused on new diagnostic applications that can increase sensitivity and specificity.

In this context, the objective of our work isto increase the sensitivity and specificity of protein detection. We used the proximity ligation assay based on western Blotting (PLA WB) for the first time to detect $R$. conorri and $R$. africae proteins. The proximity ligation assay (PLA) allows powerful localized signal amplification. This technique based on dual antibody recognition offers increased detection sensitivity and specificity (Fredriksson et al., 2002) (Blokzijl et al., 2010) (Liu et al., 2011). Here, we have adapted an ultrasensitive proximity ligation assay based on western Blotting (PLA WB) method for the detection of protein bands of $R$. conorii and R. africae at the early stage of infection. We performed a classical 1SDS-

${ }^{1}$ Corresponding author 
PAGE Western Blot which enabled us to compare both of these techniques.

In parallel, we have screened 20 rickettsial recombinant proteins by ELISA (Kowalczewska et al., 2012) with sera infected by $R$. conorii and $R$. africae, respectively. All together, these combined methods allow us to propose a few discriminate protein candidates for serodiagnostic test development.

\section{MATERIALS AND METHODS}

\section{Rickettsiae and Cells}

Rickettsia conorii (strain Seven Malish, ATCC VR-630) and Rickettsia africae (strain ESF-5) were propagated on a confluent monolayer of murine fibroblast L929 cells line and purified on renographin density gradient centrifugation as previously reported (Eremeeva et al., 1994a). Purified bacteria were resuspended in PBS and stored at $-80^{\circ} \mathrm{C}$ until its use. All purification steps were monitored by Gimenez staining (Gimenez, 1964). Protein concentration was determined by modified Bradford method (Kowalczewska et al., 2008).

\section{Preparation of Crude Extracts for SDS-PAGE}

The whole rickettsial cells purified were solubilized in Laemmli buffer (Laemmli, 1970) and separated by electrophoresis on a $10 \%$ sodium dodecyl sulfate-polyacrylamide gel for $1 \mathrm{~h}$ at 150V.All IEF (Immobiline Dry Strips gels (7 cm, pH 3-10, GE Healthcare) rehydrated with $15 \mu \mathrm{g}(7 \mathrm{~cm})$ of solubilized proteins) and 2-D electrophoresis steps were performed as previously described (Kowalczewska et al., 2008). The proteins were resolved by electrophoresis through a $10 \%$ SDS-polyacrylamide gel (EttanTM DALT, GE Healthcare) at $5 \mathrm{~W} / \mathrm{gel}$ for $30 \mathrm{~min}$, followed by $17 \mathrm{~W} / \mathrm{gel}$ for 4-5 h. Following electrophoresis, the gels were either silverstained or transferred onto nitrocellulose membranes. Digital images were generated using transmission scanning (Image Scanner, GE Healthcare).

\section{Western Blotting}

Rickettsial extracts $(15 \mu \mathrm{g})$ separated in one dimension by SDS-PAGE or 2D gel electrophoresis $(7 \mathrm{~cm}$, $\mathrm{pH} 3-10)$ were transferred onto nitrocellulose membranes (Trans-blot transfer medium, pure nitrocellulose Membrane $0.45 \mu \mathrm{m}, \mathrm{BioRad})$ at $100 \mathrm{~V}$ for $2 \mathrm{~h}$. Membranes were then blocked in PBS supplemented with $0.2 \%$ Tween 20 and 5\% non-fat dry milk (PBS-Tween-milk) for $1.5 \mathrm{~h}$ at room temperature before incubation with sera of infected patients (dilution 1:100 in the blocking buffer) or with rabbit sera (dilution 1:1000 in the blocking buffer). After $1 \mathrm{~h}$ of incubation, the membranes were washed three times for 10 min in $0.2 \%$ PBS-Tween 20 and probed with horseradish peroxidase-conjugated goat anti-human IgG (1:1000; GE Healthcare). The blots were washed three times as indicated above, and chemiluminescence kit (ECL TM Western blotting Analysis System, GE Healthcare) was used to detect protein bands. The resulting signal was detected on Hyperfilm $^{\mathrm{TM}}$ ECL and subsequently developed using an automated film processor (Hyperprocessor ${ }^{\mathrm{TM}}$, GE Healthcare).

\section{Serum Cross-Adsorption}

Sera from ten patients determined to have had $R$. conorii and from ten patients determined to have had $R$. africae were randomly selected for cross-adsorption and Western blotting studies. Two aliquots of the 10 selected sera (100 $\mathrm{ml}$ each) were each diluted 1:10 separately in an $R$. africae antigen suspension previously adjusted to contain $2 \mathrm{mg}$ of protein $/ \mathrm{ml}$ and in a $R$. conorii antigen suspension previously adjusted to contain $2 \mathrm{mg}$ of protein $/ \mathrm{ml}$ and shaken for $24 \mathrm{~h}$ at room temperature. After centrifugation at $10,000 \mathrm{x} \mathrm{g}$ for $10 \mathrm{~min}$, the supernatant was removed and treated twice again as described above (Jensenius et al., 2004). The cross-adsorption assay using $R$. africae and $R$. conorii antigens and followed by WB on the resulting supernatant wasperformed as previously described (Hechemy et al., 1983). We considered assays where adsorption with $R$. africae antigen removed both homologous and heterologous antibodies and adsorption with $R$. conorii antigen removed homologous antibodies only as serological evidence of $R$. africae infection. If these criteria were not met, the result was classified as undetermined SFG rickettsial infection. The crossadsorption assay was performed on convalescent-phase sera from all cases classified as undetermined SFG rickettsial infection by IFA and WB and with IgG titers of $>1: 64$ by IFA (La and Raoult, 1997).

\section{Proximity Ligation Assay Based on Western Blotting (PLA WB)}

The whole cells rickettsial proteins $(15 \mu \mathrm{g})$ were separated using 1D SDS-PAGE (10 \%) or 2D gel electrophoresis (7cm, $\mathrm{pH} 3-10)$, and transferred onto 
nitrocellulose membranes (Bio-Rad) using a semidry transfer unit (Hoeffer Scientific) as described previously (Kowalczewska et al., 2008). Membranes were blocked in PBS supplemented with $0.2 \%$ Tween 20 (PBST) and 5\% non-fat dry milk (PBST-milk) for $1.5 \mathrm{~h}$ at room temperature before incubation with sera of infected patients (dilution 1:100 in PBST-milk) or with rabbit sera (dilution 1:1000 in the blocking buffer). After the wash, the membrane was incubated for $1 \mathrm{~h}$ at room temperature under gentle rotation with Duolink ${ }^{\circledR}$ II PLA Plus probe (OLINK Bioscience) as described by the manufacturer. The detection probes $(0.2-1$ $\mu \mathrm{g} / \mathrm{ml})$ were diluted in PLA probe diluent buffer $(0.5 \mathrm{mg} / \mathrm{ml}$ BSA, $5 \mu \mathrm{g} / \mathrm{ml}$ salmon sperm DNA, 5mM EDTA, $0.05 \%$ Tween20 in TBS buffer). The membrane was then briefly rinsed and washed for $2 \times 10 \mathrm{~min}$ and incubated at gentle orbital rotation for $40 \mathrm{~min}$ at $37^{\circ} \mathrm{C}$ with $\mathrm{T} 4 \mathrm{DNA}$ ligase (Fermentas) (0.01-0.03 U/ $\mu \mathrm{l})$ and backbone and splint oligonucleotides (1-90 $\mathrm{nM}$ ) supplied by the manufacturer (OLINK Bioscience) and were diluted in oligo ligation buffer. Next, the membrane was washed for $5 \mathrm{~min}$ in PBST and after that incubated with phi29 DNA polymerase (GE Healthcare $)(0.01-0.125 \mathrm{U} / \mu \mathrm{l}) \quad$ in rolling circle amplification buffer for $1 \mathrm{~h}$ at $37^{\circ} \mathrm{C}$ (OLINK Bioscience). After two rinses, the membrane was incubated with dye Cy5 (5-45 nM) (Integrated DNA Technologies) in detection buffer $(2 \times S S C, 0.5 \mathrm{mg} / \mathrm{ml}$ BSA, $2 \mu \mathrm{g} / \mathrm{ml}$ salmon sperm DNA, $0-5 \%$ formamide, $0.05 \%$ Tween 20 ) for $30 \mathrm{~min}$ at $37^{\circ} \mathrm{C}$. Finally, the membrane was rinsed twice and washed for $3 \times 10 \mathrm{~min}$ in PBST and rinsed quickly in PBS to remove Tween20. Fluorescence signals were captured by using a Typhoon ${ }^{\mathrm{TM}}$ FLA 9000 imager (PMT, 450 V) (GE Healthcare).

\section{ELISA}

Modified ELISA performed with 20 recombinant rickettsial proteins, was performed as previously described (Kowalczewska et al., 2012). All steps were performed according to standard protocols (Kowalczewska et al., 2012). The human sera were diluted $1 / 1000$ in PBST-milk. Alkaline phosphatase-conjugated goat anti-human IgG (whole molecule) (Sigma) (1/5000), alkaline phosphatase yellow para-nitro-phenyl phosphate (pNPP) (Sigma) were used as described (Kowalczewska et al., 2012 ;Sekeyova et al., 2010). The reaction was read with a microplate reader (Multiskan EX, Labsystems, Thermo Fisher Scientific, Waltham, MA) at a wavelength of $405 \mathrm{~nm}$ and data analysed by GraphPad Prism (San Diego, CA). A positive control consisted in positive serum with active $R$. africae and $R$. conorii infection; a negative control consisted in negative serum. Each serum sample was tested at least in duplicate. The cut-off was determined as described (Kowalczewska et al., 2012) (Sekeyova et al., 2010). Any samples exhibiting absorbance above the cut off value was considered as positive (Figure $1 \mathrm{~A} \& \mathrm{~B}$ ).

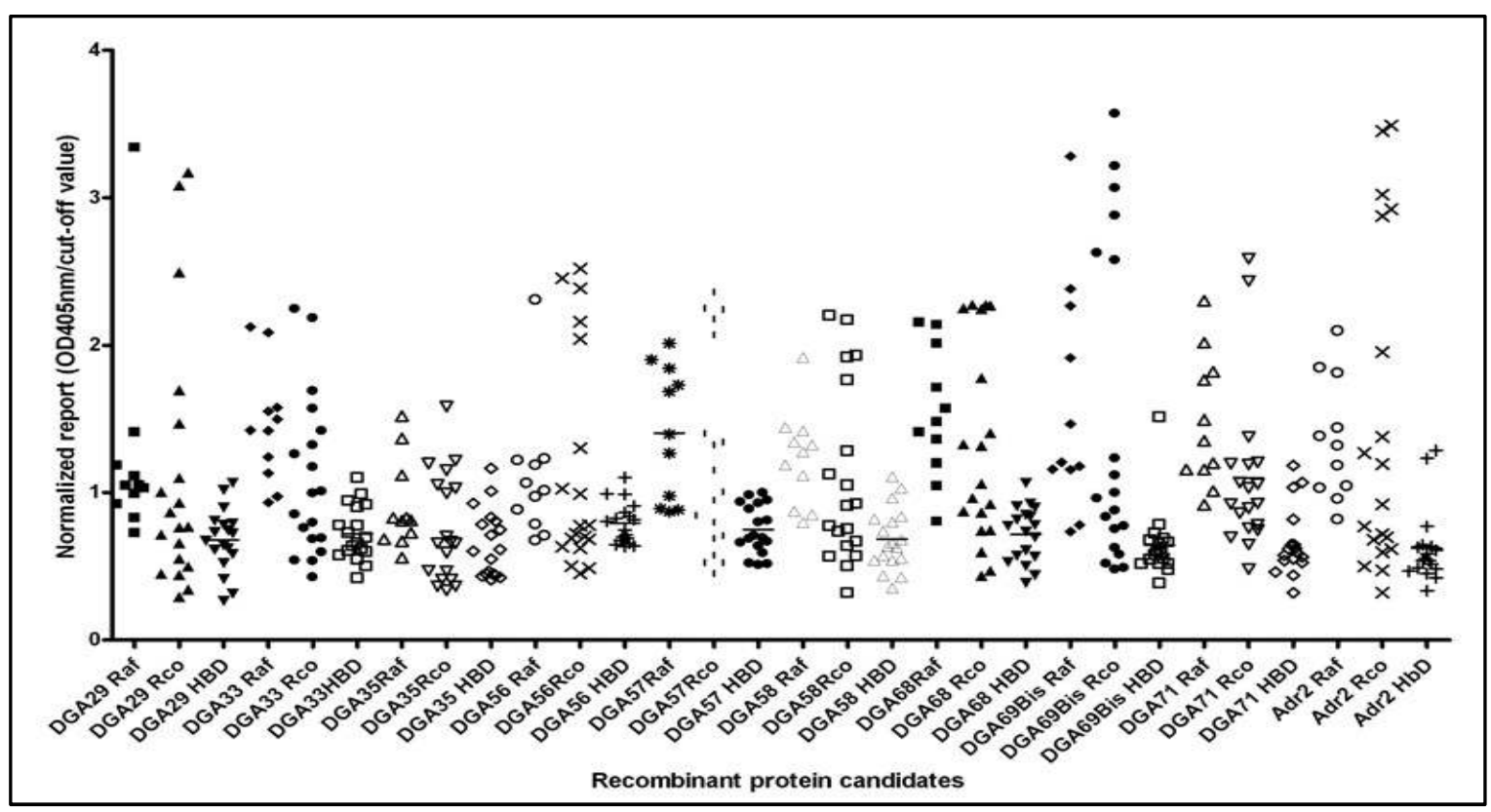

Figure 1A: The Recombinant Proteins of $R$, prowazekii, Strain MadridE 


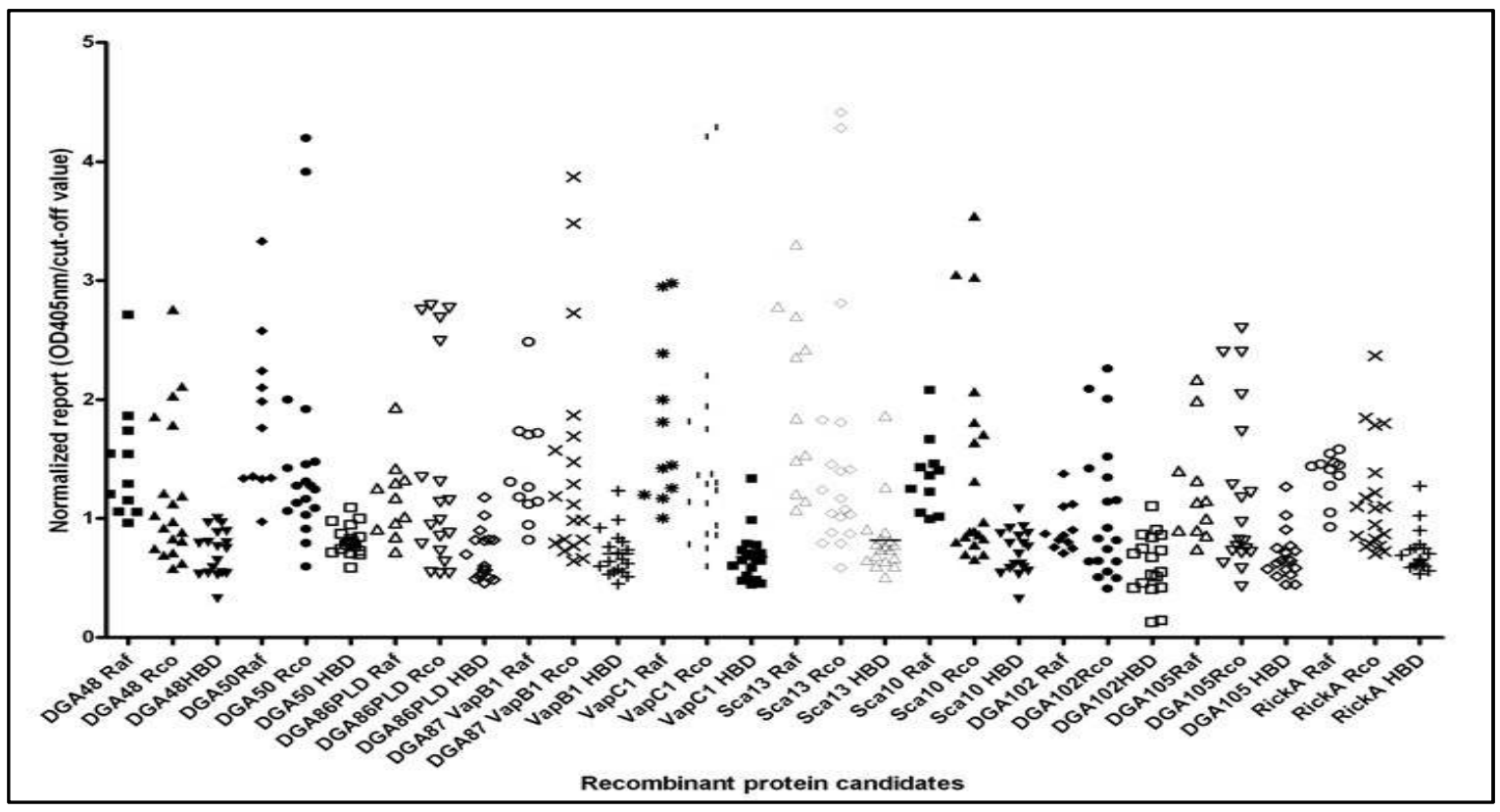

Figure 1B: The Recombinant Proteins of $R$, prowazekii, Strain Sheila Smith

\section{Human Sera and Sera of Rabbits}

For Western Blot, 22 patient's sera with an infection due to $R$. africae and 20 sera the patients diagnosed for active $R$. conorii infection diagnosed at the Unité des Rickettsies (Marseille, France) were included in this study (Kowalczewska et al., 2018). The sera of rabbits infected with $R$. conorii and $R$. africae were obtained by 2 immunizations with the bacterial suspension of $R$. conorii and $R$. africae purified by the renographin gradient method.

For ELISA, we used the same sera as for Western Blot: 11 sera of patients with $R$. africae, 19 sera with $R$. conorii infection and we enlarge to 18 of healthy blood donors (HBD). The diagnosis was based on serology and PCR assays targeting (Socolovschi et al., 2009).

\section{RESULTS AND DISCUSSION}

\section{Serum Cross-Adsorption}

The Western blot allows earlier diagnosis, but its interest lies in the accuracy of the species rickettsia or by only detecting antibodies against the species in question, or after cross adsorption eliminating non-specific antibodies (an example of this technique is illustrated in Fig. 2). We can observe a strong reactivity with the band of $50 \mathrm{kDa}$ but weakly with bands of $34 \mathrm{kDa}, 30 \mathrm{kDa}$ and $17 \mathrm{kDa} R$. conorii antigen (Figure 2). These protein bands (20-50 kDa) are specificto the lipopolysaccharide in Rickettsia (Eremeeva et al., 1994b). Cross adsorption is achieved by mixing serum studied bacteria are suspected to be cause. Resulting in a loss of homologous antibodies and heterologous adsorption occurs when the bacteria responsible of the disease, while only homologous antibodies disappear when the adsorption is performed with the bacterium responsible for the cross reactivity (Figure 2) (La and Raoult, 1997). A specific serological diagnosis of ATBF vis-a '-vis other SFG rickettsioses is sometimes of clinical and epidemiological importance. The major limitations with the cross-adsorption assay are the large amounts of antigen needed, high costs, and the fact that conclusive reactions are usually only seen in samples with pronounced immune response (e.g., with IgG titers of $>1: 64$ ) (Laet al., 2000). Indeed, 10 sera used here showed negative serology, which makes this approach limited for early stage infections. The technique is not always successful because only 4 out of 20 cases $(20 \%)$ of patient's analyzed sera have identified the Rickettsia species responsible for the disease. Serological differentiation of $20 \%$ is similar to what has been observed in Rickettsia prowazekii and Rickettsia typhi (La et al., 2000). 


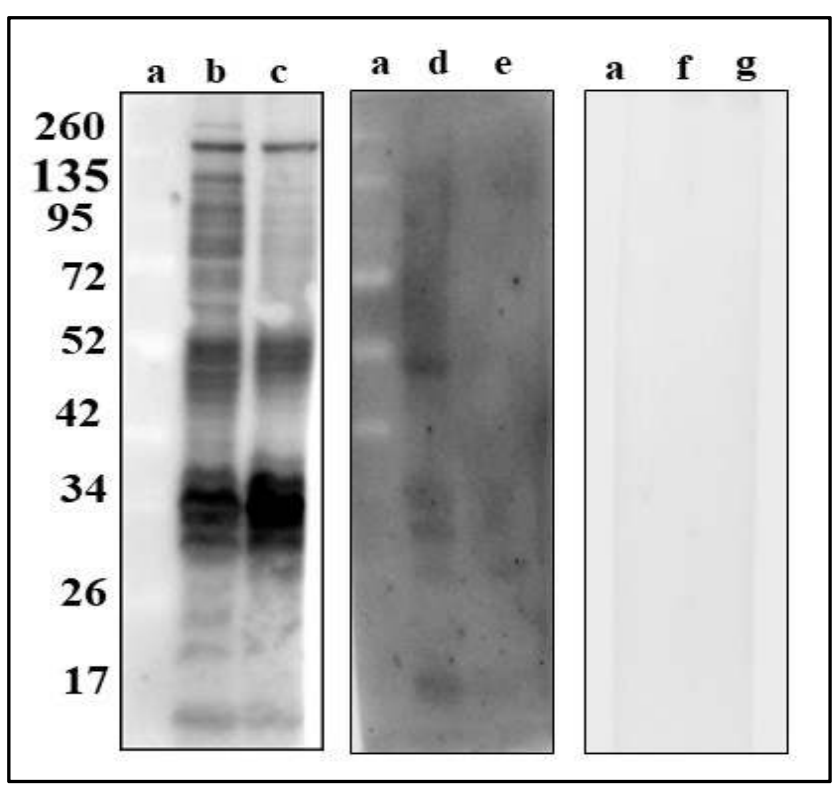

Figure 2: Example of western immunoblotting of serum samples from a patient with ATBF before and after cross-adsorption assay with $R$. conorii or $R$. africae

Considering that only $20 \%$ of samples can be confirmed by this in routine usage technique, which is so far the most useful in rickettsial species discrimination, we decided to run a challenge for rickettsial markers discovery by two approaches: proximity ligation WB and traditional 1D SDS-PAGE, respectively.

\section{Detection of Protein Bands by 1D PLA WB Method}

To increase signal amplification and detection sensitivity, we adapted PLA technique to detect rickettsial proteins bands. To determine if -in situ- PLA can provide enhanced sensitivity in WB, we compared 1D PLA WB and traditional 1D-WB. We limited to compare the number of detected bands and just visually estimate the intensity of the signal. In general, we obtained better sensitivity and specificity of bands detection in PLA WB in case of proteins probed with IFA $R$. conorii or $R$. africae positive sera (Figure 3).We noted the enhanced signal in PLA WB when comparing with traditional WB. Thus, PLA is known to enhance considerably the sensitivity (20-50 folds) (Liu et al., 2011) (Clausson et al., 2011). The improved sensitivity can also permit analysis of small amounts of sample and reducing consumption of precious samples. These results allow us to make 2D PLA WB in order to detect and identify immunogenic proteins of Rickettsia.

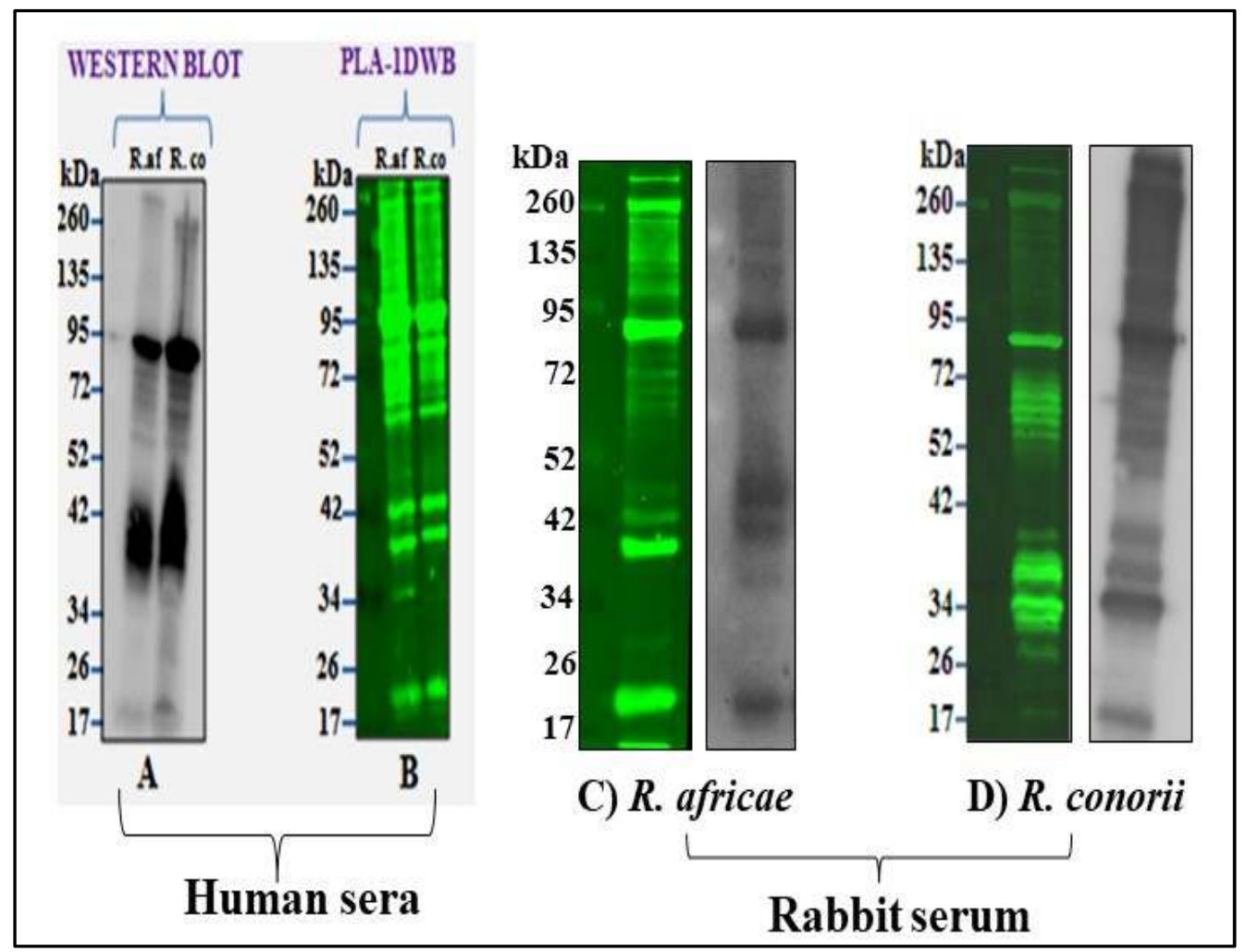

Figure 3: Example of detection of rickettsial proteins bands using traditional WB and PLA-WB 


\section{Immunoreactivity Patterns Revealed by 2-D PLA WB}

Here, we describe the preliminary results obtained with of rabbit sera for the detection of immunogenic proteins of Rickettsia conorii and Rickettsia africae with the 2D PLA WB technique (Figure 4). We adapted PLA technique to detect rickettsial proteins. To determine if in situ PLA can provide enhanced sensitivity in WB, we compare 2D PLA WB to traditional 2D WB. The immunoreactivity profiles obtained by PLA 2D WB were very similar to those obtained with traditional WB. Mainly, the zone in $\mathrm{pH}$ range 3-4.5 was highly reactive with major rOmpB spot (Kowalczewska et al., 2018). Considering that the aim of our study was global sera reactivity patterns screening, we did not perform the detailed quantifications of signals obtained by both techniques. We limited to compare the number of detected spots and just visually estimate the intensity of signal. In general, we obtained the better sensitivity and specificity of spot detection in PLA WB in case of proteins probed with IFA $R$. conorii or $R$. africae positive rabbit sera (Figure 4). Therefore, we noted the enhanced signal in PLA WB when comparing to traditional WB. Thus, PLA is known to enhance considerably the sensitivity (20-50 folds) (Liu et al., 2011) (Clausson et al., 2011). All together, the immunoreactivity profiles obtained for both $R$. africae and $R$. conorii were very similar and homogeneous and this in case for both techniques: 2D PLA-WB and traditional 2D-WB, respectively (Kowalczewska et al., 2018).

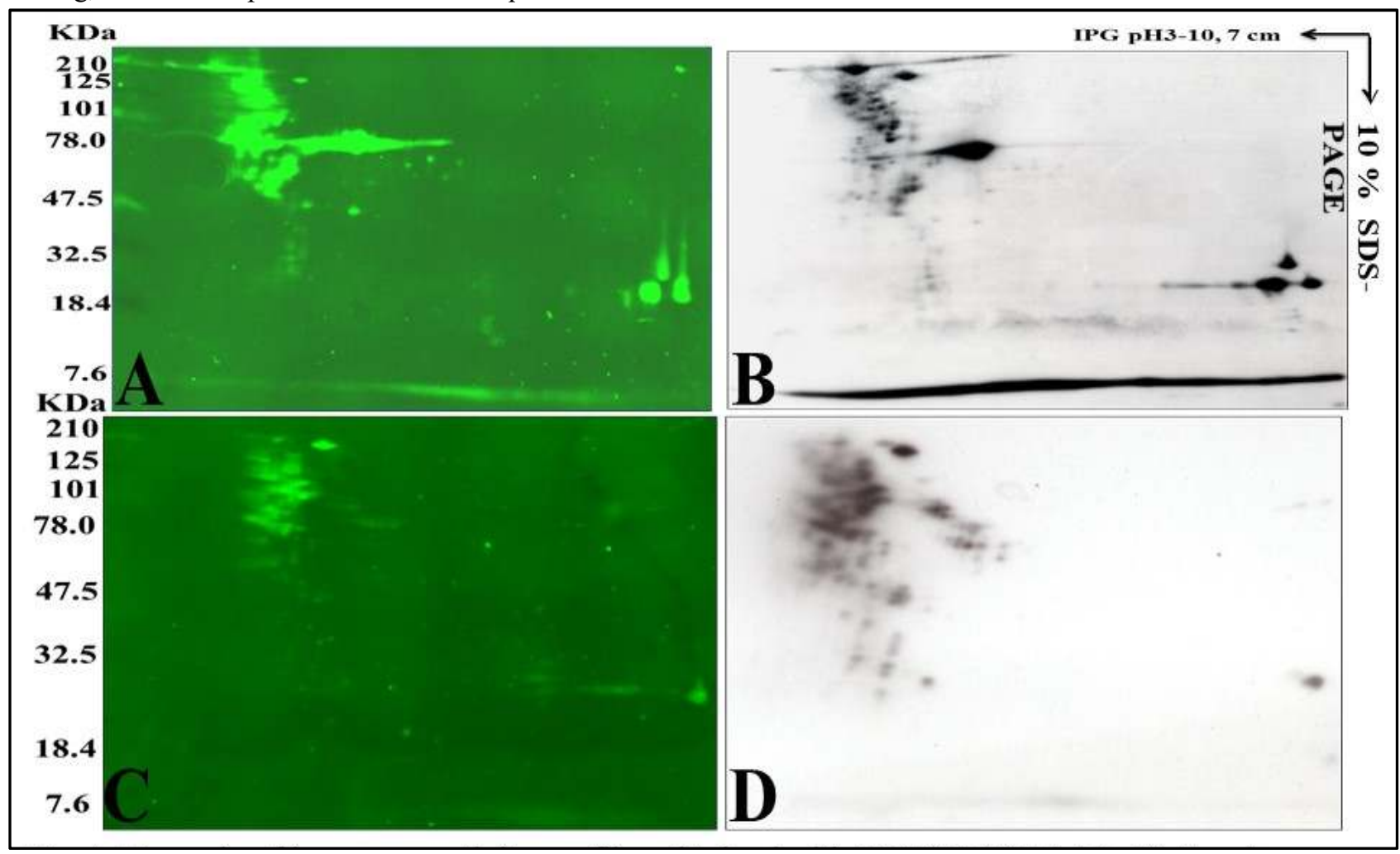

Figure 4: Example of immunoreactivity profiles obtained with PLA 2D WB (pI 3-10, 7 cm)

\section{Discriminate Recombinant Proteins}

To facilitate the discrimination between $R$. africae and $R$. conorii patients, we screened in this aim 20 recombinant proteins from a previous study (Kowalczewska et al., 2012). Several recombinant proteins were found to cross-react with both, sera infected with $R$. africae and $R$. conorii (Table 1) with the best hits for detection of both rickettiae: sca13, VapB1, atpC, spoJ. However, the reactivity of sera from $R$. africae infected patients was more intense than for $R$. conorii. This conform the results obtained with immunoblots. Not suprising that $R$. rickettsii proteins reacted better with both $R$. africae and $R$. conorii, than $R$. prowazekii recombinant proteins. Thus, several proteins were shown specific and sensitive for detection of $R$. africae (best hits: Sca10, EF-Tu, VapC1, pepA, and 
peptide $\beta$ ). However, it is important to consider a small cohort of $R$. africae infected patients ( $\mathrm{n}=11)$. As in previous study, we did not find the highly discriminate markers of $R$. conorii infection (Kowalczewska et al., 2012). Moreover, the best hits for diagnosis both $R$. conorii and $R$. typhi differs from the best hists found in the present study for diagnosis of $R$. conorii and $R$. africae infection. In the fact in both studies we observe effect of cohort over the serological parameters. Thus, it will be suitable to validate these diagnostic targets on larger study population. Considered the results, diagnostic test by ELISA can be interesting to use in routine, because of rapidity of its realization, low cost and possible development of high put screening which required only small amount of patient's sera (less than $1 \mu \mathrm{l})$. However, ELISA will be recommended to be use in parallel with IFA reference method and adsorbed western-blot which is more sensitive and allows an earlier diagnosis than IFA. The main drawback of adsorbed western blot is time-consuming, required large amount of both: patient's serum samples and bacteria. Moreover, the specific choice of bacteria to be tested is based on patient's anamnesis and the epidemiological data. Optimization of recombinant proteins based ELISA may be an interesting alternative for diagnosis of rickettsial diseases.

Table 1: Test-operating parameters of 20 recombinant proteins included in the present study

\begin{tabular}{|c|c|c|c|c|c|c|c|c|c|c|c|c|c|c|c|c|c|c|c|c|c|c|}
\hline & & & \multicolumn{6}{|c|}{ R.africae } & \multicolumn{6}{|c|}{ R.conorii } & \multicolumn{6}{|c|}{ R.africae\&R.conorii } & \multirow[t]{2}{*}{$\begin{array}{c}\text { This } \\
\text { study }\end{array}$} & \multirow[t]{2}{*}{$\begin{array}{c}\text { previousst } \\
\text { udy(1) }\end{array}$} \\
\hline DGA & & & Se & $\begin{array}{l}\text { S } \\
\mathbf{p}\end{array}$ & $\begin{array}{l}\mathbf{V} \\
\mathbf{P} \\
\mathbf{P}\end{array}$ & $\begin{array}{l}\mathbf{V} \\
\mathbf{P} \\
\mathbf{N}\end{array}$ & L & $\Lambda$ & $\begin{array}{l}\text { S } \\
\text { e }\end{array}$ & $\begin{array}{l}\mathbf{S} \\
\mathbf{p}\end{array}$ & $\begin{array}{l}\mathbf{V} \\
\mathbf{P} \\
\mathbf{P}\end{array}$ & $\begin{array}{l}\mathbf{V} \\
\mathbf{P} \\
\mathbf{N}\end{array}$ & $\mathbf{L}$ & $\Lambda$ & $\begin{array}{l}\text { S } \\
\text { e }\end{array}$ & $\begin{array}{l}\text { S } \\
\text { p }\end{array}$ & $\begin{array}{l}\mathbf{V} \\
\mathbf{P} \\
\mathbf{P}\end{array}$ & $\begin{array}{l}\mathbf{V} \\
\mathbf{P} \\
\mathbf{N}\end{array}$ & $\mathbf{L}$ & $\Lambda$ & & \\
\hline $\begin{array}{c}\text { R.prow } \\
\text { azekii } \\
\text { ME }\end{array}$ & & & & & & & & & & & & & & & & & & & & & & \\
\hline DGA35 & $\begin{array}{c}\text { groEL; } 60 \\
\text { kDchaperoni } \\
\text { n }\end{array}$ & RP626 & 25 & $\begin{array}{l}8 \\
9\end{array}$ & 60 & 64 & $\begin{array}{c}2.2 \\
5\end{array}$ & $\begin{array}{l}0.8 \\
44\end{array}$ & $\begin{array}{l}3 \\
7\end{array}$ & $\begin{array}{l}8 \\
9\end{array}$ & 78 & 57 & $\begin{array}{l}3.3 \\
16\end{array}$ & $\begin{array}{l}0.7 \\
11\end{array}$ & $\begin{array}{l}3 \\
3\end{array}$ & $\begin{array}{l}8 \\
9\end{array}$ & 83 & 44 & 3 & $\begin{array}{c}0.7 \\
5\end{array}$ & & $\begin{array}{c}\text { Marker } \\
\text { R.typhi\&R } \\
\text {. conorii }\end{array}$ \\
\hline DGA29 & $\begin{array}{c}\text { Cell surface } \\
\text { antigen Sca1 } \\
\text { (SPLIT } \\
\text { GENE) }\end{array}$ & RP016 & 72 & $\begin{array}{l}8 \\
9\end{array}$ & 80 & 84 & $\begin{array}{c}6.5 \\
4\end{array}$ & $\begin{array}{l}0.3 \\
06\end{array}$ & $\begin{array}{l}3 \\
7\end{array}$ & $\begin{array}{l}8 \\
9\end{array}$ & 78 & 57 & $\begin{array}{l}3.3 \\
16\end{array}$ & $\begin{array}{l}0.7 \\
11\end{array}$ & $\begin{array}{l}5 \\
0\end{array}$ & $\begin{array}{l}8 \\
9\end{array}$ & 89 & 52 & $\begin{array}{c}4 . \\
5\end{array}$ & $\begin{array}{l}0.5 \\
63\end{array}$ & & $\begin{array}{l}\text { Marker } \\
\text { R.typhi }\end{array}$ \\
\hline Adr2 & $\begin{array}{l}\text { Putative outer } \\
\text { surface } \\
\text { protein } \\
\text { (Adr2) }\end{array}$ & RP828 & 81 & $\begin{array}{l}8 \\
9\end{array}$ & 81 & 89 & $\begin{array}{c}7.3 \\
6\end{array}$ & 0.2 & $\begin{array}{l}4 \\
7\end{array}$ & $\begin{array}{l}8 \\
8\end{array}$ & 81 & 61 & $\begin{array}{c}4.2 \\
6\end{array}$ & $\begin{array}{c}0.5 \\
9\end{array}$ & $\begin{array}{l}6 \\
0\end{array}$ & $\begin{array}{l}8 \\
9\end{array}$ & 90 & 57 & $\begin{array}{l}5 . \\
4\end{array}$ & $\begin{array}{c}0.4 \\
5\end{array}$ & & $\begin{array}{c}\text { Marker } \\
\text { R.typhi\&R } \\
\text {. conorii }\end{array}$ \\
\hline $\begin{array}{c}\text { DGA69 } \\
\text { Bis }\end{array}$ & $\begin{array}{c}\text { DOMAINE } \\
\text { PFAM 447- } \\
768 \text { omp1 }\end{array}$ & RP160 & 82 & $\begin{array}{l}9 \\
4\end{array}$ & 90 & 89 & $\begin{array}{l}14 . \\
72\end{array}$ & $\begin{array}{l}0.1 \\
925\end{array}$ & $\begin{array}{l}4 \\
2\end{array}$ & $\begin{array}{l}9 \\
4\end{array}$ & 89 & 60 & $\begin{array}{c}7.5 \\
7\end{array}$ & $\begin{array}{c}0.6 \\
1\end{array}$ & $\begin{array}{l}5 \\
6\end{array}$ & $\begin{array}{l}9 \\
4\end{array}$ & 94 & 56 & $\begin{array}{l}10 \\
.2\end{array}$ & $\begin{array}{c}0.4 \\
5\end{array}$ & $\begin{array}{c}\text { mark } \\
\text { er } \\
\text { Raf }\end{array}$ & \\
\hline DGA33 & $\begin{array}{c}\text { Aminopeptid } \\
\text { ase A } \\
\text { (EC:3.4.11.1) } \\
\text { (pepA) }\end{array}$ & RP142 & 82 & $\begin{array}{l}9 \\
4\end{array}$ & 90 & 89 & $\begin{array}{l}14 . \\
72\end{array}$ & $\begin{array}{c}0.1 \\
925\end{array}$ & $\begin{array}{l}5 \\
2\end{array}$ & $\begin{array}{l}9 \\
4\end{array}$ & 90 & 65 & $\begin{array}{l}9.4 \\
74\end{array}$ & $\begin{array}{l}0.5 \\
02\end{array}$ & $\begin{array}{l}6 \\
3\end{array}$ & $\begin{array}{l}9 \\
4\end{array}$ & 95 & 60 & $\begin{array}{l}11 \\
.4\end{array}$ & $\begin{array}{l}0.3 \\
88\end{array}$ & $\begin{array}{c}\text { mark } \\
\text { er } \\
\text { Raf }\end{array}$ & \\
\hline DGA58 & $\begin{array}{l}\text { hypotheticalp } \\
\text { rotein RP631 }\end{array}$ & RP631 & 72 & $\begin{array}{l}8 \\
9\end{array}$ & 80 & 84 & $\begin{array}{c}6.5 \\
4\end{array}$ & $\begin{array}{l}0.3 \\
06\end{array}$ & $\begin{array}{l}4 \\
2\end{array}$ & $\begin{array}{l}8 \\
9\end{array}$ & 80 & 59 & $\begin{array}{c}3.7 \\
9\end{array}$ & $\begin{array}{c}0.6 \\
51\end{array}$ & $\begin{array}{l}5 \\
3\end{array}$ & $\begin{array}{l}8 \\
8\end{array}$ & 88 & 53 & $\begin{array}{l}4 . \\
8\end{array}$ & $\begin{array}{l}0.5 \\
25\end{array}$ & & \\
\hline DGA57 & $\begin{array}{c}\text { 3- } \\
\text { demethylubiq } \\
\text { uinone-9 3- } \\
\text { methyltransfe } \\
\text { rase }\end{array}$ & RP622 & 64 & $\begin{array}{l}1 \\
0 \\
0\end{array}$ & $\begin{array}{c}10 \\
0\end{array}$ & 82 & - & $\begin{array}{l}0.3 \\
63\end{array}$ & $\begin{array}{l}5 \\
3\end{array}$ & $\begin{array}{l}1 \\
0 \\
0\end{array}$ & $\begin{array}{c}10 \\
0\end{array}$ & 66 & - & $\begin{array}{c}0.4 \\
73\end{array}$ & $\begin{array}{l}5 \\
7\end{array}$ & $\begin{array}{l}1 \\
0 \\
0\end{array}$ & $\begin{array}{c}10 \\
0\end{array}$ & 58 & - & $\begin{array}{l}0.4 \\
33\end{array}$ & & \\
\hline DGA56 & $\begin{array}{c}\text { UDP-N- } \\
\text { acetylmurama } \\
\text { te--L-alanine } \\
\text { ligase }\end{array}$ & $\begin{array}{l}\mathrm{RP} 247 \\
\text { (murC) }\end{array}$ & $\begin{array}{l}54 \\
.5\end{array}$ & $\begin{array}{l}9 \\
4\end{array}$ & 86 & 77 & $\begin{array}{c}9.8 \\
18\end{array}$ & $\begin{array}{l}0.4 \\
81\end{array}$ & $\begin{array}{l}3 \\
7\end{array}$ & $\begin{array}{l}9 \\
4\end{array}$ & $\begin{array}{l}87 \\
.5\end{array}$ & $\begin{array}{c}58 . \\
6\end{array}$ & $\begin{array}{l}6.6 \\
32\end{array}$ & $\begin{array}{l}0.6 \\
69\end{array}$ & $\begin{array}{l}4 \\
3\end{array}$ & $\begin{array}{l}9 \\
4\end{array}$ & 93 & 50 & $\begin{array}{l}7 . \\
8\end{array}$ & 0.6 & & $\begin{array}{c}\text { Marker } \\
\text { R.typhi\&R } \\
\text {. conorii }\end{array}$ \\
\hline
\end{tabular}




\begin{tabular}{|c|c|c|c|c|c|c|c|c|c|c|c|c|c|c|c|c|c|c|c|c|c|c|}
\hline DGA68 & $\begin{array}{c}\text { stage 0 } \\
\text { sporulation } \\
\text { protein J } \\
(\text { spo0J) }\end{array}$ & RP059 & 91 & $\begin{array}{l}9 \\
4\end{array}$ & 90 & 94 & $\begin{array}{l}16 . \\
36\end{array}$ & $\begin{array}{c}0.0 \\
9\end{array}$ & $\begin{array}{l}5 \\
8\end{array}$ & $\begin{array}{l}9 \\
4\end{array}$ & 92 & 68 & $\begin{array}{l}10 . \\
42\end{array}$ & $\begin{array}{l}0.4 \\
45\end{array}$ & $\begin{array}{l}7 \\
0\end{array}$ & $\begin{array}{l}9 \\
4\end{array}$ & 95 & 65 & $\begin{array}{l}12 \\
.6\end{array}$ & $\begin{array}{l}0.3 \\
17\end{array}$ & $\begin{array}{c}\text { mark } \\
\text { er } \\
\text { Raf\& } \\
\text { Rco }\end{array}$ & \\
\hline DGA71 & $\begin{array}{c}\text { signal } \\
\text { recognition } \\
\text { particleprotei } \\
\text { n }\end{array}$ & RP173 & 90 & $\begin{array}{l}8 \\
3\end{array}$ & 77 & 94 & $\begin{array}{c}5.4 \\
5\end{array}$ & $\begin{array}{l}0.1 \\
09\end{array}$ & $\begin{array}{l}4 \\
7\end{array}$ & $\begin{array}{l}8 \\
3\end{array}$ & 75 & 60 & $\begin{array}{c}2.8 \\
4\end{array}$ & $\begin{array}{c}0.6 \\
3\end{array}$ & $\begin{array}{l}6 \\
3\end{array}$ & $\begin{array}{l}8 \\
3\end{array}$ & 86 & 57 & $\begin{array}{l}3 . \\
8\end{array}$ & $\begin{array}{c}0.4 \\
4\end{array}$ & & $\begin{array}{l}\text { Marker } \\
\text { R.typhi }\end{array}$ \\
\hline $\begin{array}{c}R . \\
\text { rickettsi } \\
i \text { Sheila } \\
\text { Smith }\end{array}$ & & & & & & & & & & & & & & & & & & & & & & \\
\hline DGA50 & $\begin{array}{c}\text { F0F1 ATP } \\
\text { synthase } \\
\text { subunit } \\
\text { epsilon }\end{array}$ & $\begin{array}{l}\text { A1G_0 }^{2} \\
6755 \\
\text { (atpC) }\end{array}$ & 91 & $\begin{array}{l}9 \\
4\end{array}$ & 90 & 94 & $\begin{array}{l}16 . \\
36\end{array}$ & $\begin{array}{c}0.0 \\
9\end{array}$ & $\begin{array}{l}8 \\
4\end{array}$ & $\begin{array}{l}9 \\
4\end{array}$ & 94 & 85 & $\begin{array}{l}15 . \\
15\end{array}$ & $\begin{array}{l}0.1 \\
67\end{array}$ & $\begin{array}{l}8 \\
7\end{array}$ & $\begin{array}{l}9 \\
4\end{array}$ & 96 & 81 & $\begin{array}{l}15 \\
.6\end{array}$ & $\begin{array}{c}0.1 \\
4\end{array}$ & $\begin{array}{c}\text { mark } \\
\text { er } \\
\text { Raf\& } \\
\text { Rco }\end{array}$ & \\
\hline $\begin{array}{l}\text { DGA88 } \\
\text { VapC1 }\end{array}$ & $\begin{array}{c}\text { hypotheticalp } \\
\text { rotein } \\
\text { A1G_02180 } \\
(\mathrm{VapC} 1)\end{array}$ & $\begin{array}{c}\text { AG1_0 } \\
2180 \\
\text { (VapC1 } \\
\text { ) }\end{array}$ & $\begin{array}{c}10 \\
0\end{array}$ & $\begin{array}{l}9 \\
4\end{array}$ & 92 & $\begin{array}{c}10 \\
0\end{array}$ & 18 & 0 & $\begin{array}{l}6 \\
8\end{array}$ & $\begin{array}{l}9 \\
4\end{array}$ & 93 & 74 & $\begin{array}{c}12 . \\
3\end{array}$ & $\begin{array}{c}0.3 \\
3\end{array}$ & $\begin{array}{l}8 \\
0\end{array}$ & $\begin{array}{l}9 \\
4\end{array}$ & 96 & 74 & $\begin{array}{l}14 \\
.4\end{array}$ & $\begin{array}{c}0.2 \\
11\end{array}$ & $\begin{array}{c}\text { mark } \\
\text { er } \\
\text { Raf }\end{array}$ & \\
\hline $\begin{array}{l}\text { DGA87 } \\
\text { VapB1 }\end{array}$ & $\begin{array}{l}\text { hypotheticalp } \\
\text { rotein } \\
\text { A1G_02185 } \\
\text { (VapB1) }\end{array}$ & $\begin{array}{c}\text { A1G_0 } \\
2185 \\
\text { (VapB1 } \\
\text { ) }\end{array}$ & 82 & $\begin{array}{l}9 \\
4\end{array}$ & 90 & 89 & $\begin{array}{l}14 . \\
72\end{array}$ & $\begin{array}{l}0.1 \\
925\end{array}$ & $\begin{array}{l}5 \\
3\end{array}$ & $\begin{array}{l}9 \\
4\end{array}$ & 90 & 65 & $\begin{array}{c}9.4 \\
7\end{array}$ & $\begin{array}{c}0.5 \\
0\end{array}$ & $\begin{array}{l}6 \\
3\end{array}$ & $\begin{array}{l}9 \\
4\end{array}$ & 95 & 60 & $\begin{array}{l}11 \\
.4\end{array}$ & $\begin{array}{c}0.3 \\
9\end{array}$ & $\begin{array}{c}\text { mark } \\
\text { er } \\
\text { Raf\& } \\
\text { Rco }\end{array}$ & \\
\hline $\begin{array}{l}\text { DGA56 } \\
\text { PLD }\end{array}$ & $\begin{array}{c}\text { hypotheticalp } \\
\text { rotein } \\
\text { A1G_06970 } \\
\text { (PLD) }\end{array}$ & $\begin{array}{c}\mathrm{A}_{1 \mathrm{G}} 0 \\
6970 \\
\text { (PLD) }\end{array}$ & 64 & $\begin{array}{l}8 \\
9\end{array}$ & 77 & 80 & $\begin{array}{c}5.7 \\
2\end{array}$ & $\begin{array}{c}0.4 \\
0\end{array}$ & $\begin{array}{l}4 \\
7\end{array}$ & $\begin{array}{l}8 \\
9\end{array}$ & 81 & 61 & $\begin{array}{c}4.2 \\
6\end{array}$ & $\begin{array}{c}0.5 \\
9\end{array}$ & $\begin{array}{l}5 \\
3\end{array}$ & $\begin{array}{l}8 \\
9\end{array}$ & 89 & 53 & $\begin{array}{l}4 . \\
8\end{array}$ & $\begin{array}{l}0.5 \\
25\end{array}$ & & $\begin{array}{l}\text { Marker } \\
\text { R.typhi }\end{array}$ \\
\hline $\begin{array}{c}\text { DGA92 } \\
\text { Sca13 }\end{array}$ & $\begin{array}{c}\text { cell surface } \\
\text { antigen-like } \\
\text { protein Sca13 }\end{array}$ & $\begin{array}{c}\text { A1G_0 } \\
6915( \\
\text { Sca13) }\end{array}$ & $\begin{array}{c}10 \\
0\end{array}$ & $\begin{array}{l}9 \\
4\end{array}$ & 92 & $\begin{array}{c}10 \\
0\end{array}$ & 18 & 0 & $\begin{array}{l}7 \\
4\end{array}$ & $\begin{array}{l}9 \\
5\end{array}$ & 93 & 72 & $\begin{array}{l}13 . \\
26\end{array}$ & $\begin{array}{c}0.2 \\
8\end{array}$ & $\begin{array}{l}9 \\
3\end{array}$ & $\begin{array}{l}9 \\
4\end{array}$ & 96 & 77 & 15 & $\begin{array}{l}0.1 \\
76\end{array}$ & $\begin{array}{c}\text { mark } \\
\text { er } \\
\text { Raf\& } \\
\text { Rco }\end{array}$ & \\
\hline $\begin{array}{c}\text { DGA10 } \\
5\end{array}$ & sojprotein & $\begin{array}{c}\mathrm{A}^{\mathrm{A} \mathrm{G}_{-} 0} \\
0540\end{array}$ & 54 & $\begin{array}{l}8 \\
9\end{array}$ & 75 & 76 & 4.9 & $\begin{array}{l}0.5 \\
11\end{array}$ & $\begin{array}{l}4 \\
2\end{array}$ & $\begin{array}{l}8 \\
9\end{array}$ & 80 & 59 & $\begin{array}{c}3.7 \\
8\end{array}$ & $\begin{array}{c}0.6 \\
5\end{array}$ & $\begin{array}{l}4 \\
7\end{array}$ & $\begin{array}{l}8 \\
9\end{array}$ & $\begin{array}{l}87 \\
.5\end{array}$ & 50 & $\begin{array}{l}4 . \\
2\end{array}$ & 0.6 & & \\
\hline $\begin{array}{c}\text { DGA93 } \\
\text { Sca10 }\end{array}$ & $\begin{array}{c}\text { cell surface } \\
\text { antigen-like } \\
\text { protein Sca10 }\end{array}$ & $\begin{array}{c}\text { A1G_0 } \\
0295 \\
\text { (Sca10) }\end{array}$ & $\begin{array}{c}10 \\
0\end{array}$ & $\begin{array}{l}9 \\
4\end{array}$ & 92 & $\begin{array}{c}10 \\
0\end{array}$ & 18 & 0 & $\begin{array}{l}4 \\
2\end{array}$ & $\begin{array}{l}9 \\
4\end{array}$ & 89 & 60 & $\begin{array}{c}7.5 \\
7\end{array}$ & $\begin{array}{c}0.6 \\
1\end{array}$ & $\begin{array}{l}6 \\
3\end{array}$ & $\begin{array}{l}9 \\
4\end{array}$ & 95 & 60 & $\begin{array}{l}11 \\
.4\end{array}$ & $\begin{array}{c}0.3 \\
9\end{array}$ & $\begin{array}{c}\text { mark } \\
\text { er } \\
\text { Raf }\end{array}$ & $\begin{array}{l}\text { Marker } \\
\text { R.typhi }\end{array}$ \\
\hline $\begin{array}{c}\text { DGA10 } \\
2\end{array}$ & $\begin{array}{l}\text { dihydrofolate } \\
\text { reductase }\end{array}$ & $\begin{array}{c}\mathrm{A}_{0} \mathrm{G}_{-} 0 \\
0215\end{array}$ & 27 & $\begin{array}{l}9 \\
4\end{array}$ & 75 & 68 & 4.9 & $\begin{array}{c}0.7 \\
7\end{array}$ & $\begin{array}{l}4 \\
2\end{array}$ & $\begin{array}{l}9 \\
4\end{array}$ & 89 & 60 & 7.6 & $\begin{array}{c}0.6 \\
1\end{array}$ & $\begin{array}{l}3 \\
7\end{array}$ & $\begin{array}{l}9 \\
4\end{array}$ & 92 & 47 & $\begin{array}{l}6 . \\
6\end{array}$ & $\begin{array}{c}0.6 \\
7\end{array}$ & & \\
\hline $\begin{array}{c}\text { DGA12 } \\
0 \\
\text { RickA }\end{array}$ & $\begin{array}{l}\text { Hypothetical } \\
\text { protein } \\
\text { A1G_05015 } \\
\text { (RickA) }\end{array}$ & $\begin{array}{c}\text { A1G_0 } \\
5015 \\
\text { (RickA } \\
\text { ) }\end{array}$ & 90 & $\begin{array}{l}8 \\
9\end{array}$ & 33 & 94 & $\begin{array}{c}8.1 \\
8\end{array}$ & $\begin{array}{l}0.1 \\
02\end{array}$ & $\begin{array}{l}5 \\
2\end{array}$ & $\begin{array}{l}8 \\
8\end{array}$ & 83 & 64 & $\begin{array}{c}4.7 \\
4\end{array}$ & $\begin{array}{l}0.5 \\
32\end{array}$ & $\begin{array}{l}6 \\
7\end{array}$ & $\begin{array}{l}8 \\
9\end{array}$ & 90 & $\begin{array}{c}61 . \\
5\end{array}$ & 6 & $\begin{array}{l}0.3 \\
75\end{array}$ & & $\begin{array}{l}\text { Marker } \\
\text { R.typhi }\end{array}$ \\
\hline DGA48 & $\begin{array}{c}\text { elongation } \\
\text { factor } \mathrm{Tu}\end{array}$ & $\begin{array}{c}\text { A1G_0 } \\
5565\end{array}$ & 90 & $\begin{array}{l}9 \\
4\end{array}$ & 90 & 94 & $\begin{array}{l}16 . \\
36\end{array}$ & $\begin{array}{c}0.0 \\
9\end{array}$ & $\begin{array}{l}4 \\
7\end{array}$ & $\begin{array}{l}9 \\
4\end{array}$ & 90 & 63 & $\begin{array}{c}8.5 \\
2\end{array}$ & $\begin{array}{c}0.5 \\
6\end{array}$ & $\begin{array}{l}6 \\
3\end{array}$ & $\begin{array}{l}9 \\
4\end{array}$ & 95 & 60 & $\begin{array}{l}11 \\
.4\end{array}$ & $\begin{array}{c}0.3 \\
9\end{array}$ & $\begin{array}{c}\text { mark } \\
\text { er } \\
\text { Raf }\end{array}$ & $\begin{array}{c}\text { Marker } \\
\text { R.typhi\& } R \\
\text {. conorii }\end{array}$ \\
\hline
\end{tabular}

Test-operating parameters :

Sensitivity $(\mathrm{Se})=$ positive result with patients/total number of patients

Specificity $(\mathrm{Sp})=$ negative result with control group/total number of individual blood donor

Positive predictive value $(\mathrm{PPV})=\mathrm{TP} /(\mathrm{TP}+\mathrm{FP})$; true positive $(\mathrm{TP})$, false positive $(\mathrm{FP})$

Negative predictive value $(\mathrm{NPV})=\mathrm{TN} /(\mathrm{TN}+\mathrm{FN})$; true negative $(\mathrm{TN})$, false negative $(\mathrm{FN})$

$\mathrm{L}=\mathrm{Se} /(1-\mathrm{Sp})=(\mathrm{TP} /$ patients $)(\mathrm{FP} /$ individualblooddonor $)$

$\Lambda=(1-\mathrm{Se}) / \mathrm{Sp}=(\mathrm{FN} /$ patients $)(\mathrm{TN} /$ individualblooddonor $)$ 


\section{CONCLUSION}

In conclusion, we have detected of immunogenic proteins from Rickettsia conorii and Rickettsia africaeby proximity ligation assay based Western blotting (PLA WB). However, it still required optimization for Rickettsiae. The preliminary results obtained with 20 recombinant proteins of $R$. africae and $R$. conorii which may be useful tools in the detection of Rickettsiae in clinical samples. ELISA performed with recombinant proteins is a valuable tool to enable the evaluation of the best targets. Several recombinant proteins were found to cross-react with both, sera infected with $R$. africae and $R$. conorii. Optimization of recombinant proteins based ELISA may be an interesting alternative for diagnosis of rickettsial diseases.

\section{REFERENCES}

Blokzijl A., Friedman M., Ponten F. and Landegren U., 2010. Profiling protein expression and interactions: proximity ligation as a tool for personalized medicine. J. Intern. Med., 268: 232245 .

Clausson C.M., Allalou A., Weibrecht I., Mahmoudi S., Farnebo M., Landegren U., Wahlby C. and Soderberg O., 2011. Increasing the dynamic range of in situ PLA. Nat. Methods, 8: 892-893.

Eremeeva M.E. and Dasch G.A., 2015. Challenges posed by tick-borne rickettsiae: eco-epidemiology and public health implications. Front Public Health, 3:1-17.

Eremeeva M.E., Balayeva N.M. and Raoult D., 1994a. Purification of rickettsial cultures contaminated by mycoplasmas. Acta Virol, 38: 231-233.

Eremeeva M.E., Balayeva N.M. and Raoult D., 1994b. Serological response of patients suffering from primary and recrudescent typhus: comparison of complement fixation reaction, Weil-Felix test, microimmunofluorescence, and immunoblotting. Clin Diagn Lab Immunol, 1: 318-324.

Fredriksson S., Gullberg M., Jarvius J., Olsson C., Pietras K., Gustafsdottir S.M., Ostman A. and Landegren U., 2002. Protein detection using proximitydependent DNA ligation assays. Nat Biotechnol, 20: 473-477.
Gimenez D.F., 1964. Staining rickettsiae in yolk-sac cultures. Stain Technol, 39: 135-1406.

Hechemy K.E., Anacker R.L., Carlo N.L., Fox J.A. and Gaafar H.A., 1983. Absorption of Rickettsia rickettsii antibodies by Rickettsia rickettsii antigens in four diagnostic tests. J. Clin. Microbiol, 17:445-449.

Jensenius M., Fournier P.E., Vene S., Ringertz S.H., Myrvang B. and Raoult D., 2004. Comparison of immunofluorescence, Western blotting, and crossadsorption assays for diagnosis of African tick bite fever. Clin Diagn Lab Immunol, 11: 786-788.

Kowalczewska M., Fenollar F., Villard C., Azza S., Roux M. and Raoult D., 2008. An immunoproteomic approach for identification of clinical biomarkers of Whipple's disease. Proteomics Clin Appl., 2: 504-516.

Kowalczewska M., N'Djatchi A., Nappez C., Alwassouf S., Decloquement P., Armstrong N., Karkouri K.E., Edouard S. and Raoult D., 2018. Identification of rickettsia limmunore active proteins using a proximity ligation assay Western blotting and the traditional immunoproteomic approach. Comp Immunol Microbiol Infect Dis, 58: 17-25.

Kowalczewska M., Vellaiswamy M., Nappez C., Vincentelli R., Scola B.L. and Raoult D., 2012. Protein candidates for the serodiagnosis of rickettsioses. FEMS Immunol Med Microbiol, 64(1):130-3.

Laemmli U.K., 1970. Cleavage of structural proteins during the assembly of the head of bacteriophage T4 Nature, 227: 680-685.

La S.B. and Raoult D., 1997. Laboratory diagnosis of rickettsioses: current approaches to diagnosis of old and new rickettsial diseases. J. Clin Microbiol., 35: 2715-2727.

La S.B., Rydkina L., Ndihokubwayo J.B., Vene S. and Raoult D., 2000. Serological differentiation of murine typhus and epidemic typhus using crossadsorption and Western blotting. Clin. Diagn. Lab Immunol, 7 : 612-616. 
Liu Y., Gu J., Hagner-McWhirter A., Sathiyanarayanan P., Gullberg M., Soderberg O., Johansson J., Hammond M., Ivansson D. and Landegren U., 2011. Western blotting via proximity ligation for high performance protein analysis. Mol. Cell Proteomics, 10 : 1-9.

Merhej V., El K.K. and Raoult D., 2009. Whole genomebased phylogenetic analysis of Rickettsiae. Clin. Microbiol. Infect, 15 Suppl 2: 336-337.

Mouffok N., Socolovschi C., Benabdellah A., Renvoise A., Parola P. and Raoult D., 2011. Diagnosis of rickettsioses from eschar swab samples, Algeria. Emerg. Infect. Dis., 17: 1968-1969.

Parola P., Jourdan J. and Raoult D., 1998. Tick-borne infection caused by Rickettsia africae in the West Indies. N. Engl. J. Med., 338: 1391-1392.

Parola P. and Paddock C.D., 2012. Ticks and tick-borne diseases. Editorial. Ticks. Tick. Borne. Dis., 3: 269-414.

Parola P., Labruna M.B. and Raoult D., 2009. Tick-borne rickettsioses in America: unanswered questions and emerging diseases. Curr. Infect. Dis. Rep., 11: 40-50.

Renvoise A. and Raoult D., 2009b. (An update on rickettsiosis). Med. Mal Infect, 39: 71-81.

Renvoise A., Rolain J.M., Socolovschi C. and Raoult D., 2012. Widespread use of real-time PCR for rickettsial diagnosis. FEMS Immunol. Med. Microbiol, 64: 126-129.

Roux V., Rydkina E., Eremeeva M. and Raoult D., 1997. Citrate synthase gene comparison, a new tool for phylogenetic analysis, and its application for the rickettsiae. Int J Syst Bacteriol, 47(2):252-261.

Sekeyova Z., Kowalczewska M., Vincentelli R., Decloquement P., Flores-Ramirez G. and Skultety L., 2010. Characterization of antigens for Q fever serodiagnostics. Acta Virol, 54(3):173-180.

Socolovschi C., Mediannikov O., Raoult D. and Parola P., 2009. Update on tick-borne bacterial diseases in Europe. Parasite, 16(4):259-273. 